\title{
De "Corações de Pedra" a "Corações de Carne": Algumas Considerações sobre a Conversão de "Bandidos" a Igrejas Evangélicas Pentecostais*
}

\section{Cesar Pinheiro Teixeira}

Doutorando em Sociologia pelo Programa de Pós-Graduação em Sociologia e Antropologia da Universidade Federal do Rio de Janeiro (UFRJ) e pesquisador do Núcleo de Estudos da Cidadania, Conflito e Violência Urbana (NECVU/UFRJ) e do Coletivo de Estudos sobre Violência e Sociabilidade (CEVIS/IESP/UERJ). Rio de Janeiro, RJ, Brasil (e-mail: cesarpinheiroteixeira@gmail.com).

1R andidos" e "crentes" convivem diariamente nas favelas das grandes cidades brasileiras. Como já mostraram alguns autores (Almeida e Montero, 1994; Fernandes, 1998), o pentecostalismo cresce com maior velocidade entre as camadas mais empobrecidas da população. E as áreas mais pobres das grandes cidades são também as que mais sofrem com o problema da violência, seja devido à presença autoritária e violenta de quadrilhas de narcotraficantes (Cano, 1995) seja por conta da violência policial (Cano, 1997). Denominações como a Assembleia de Deus tendem a se destacar mais nesses contextos ${ }^{1}$. Mafra (1998), por exemplo, ressalta que os pentecostais dão respostas de caráter espiritual ao problema da violência, de modo que não criam uma oposição direta em relação ao tráfico, ou melhor, não criam um movimento de afastamento dos "crentes" em relação aos "bandidos" mesmo que os primeiros vejam os segundos como parte do "exército do Demônio". Ao contrário, o caráter proselitista do pentecostalismo produz uma aproximação bastante significativa entre esses dois grupos - embora esse acercamento seja sempre realizado de maneira cuidadosa pelos fiéis pentecostais, pois estes geralmente temem uma "poluição moral" quando estabelecem tais contatos (Teixeira, 2008).

\footnotetext{
* Gostaria de agradecer aos professores Michel Misse e Emerson Giumbelli (meus orientadores) e à professora Diana Lima, grandes incentivadores da publicação deste artigo.

DADOS - Revista de Ciências Sociais, Rio de Janeiro, vol. 54, nº3, 2011, pp. 449 a 478.
} 
De maneira geral, mas principalmente nesses contextos, a conversão religiosa é vista como uma "saída", uma "alternativa à vida do crime". É importante destacar que a conversão religiosa é vista dessa forma não apenas pelos "crentes", mas também pelos próprios "bandidos". Mais que isso: muitos "bandidos" afirmam, seguindo o discurso dos próprios pentecostais, que a conversão é de fato a "única saída". E é nesse contexto e com esse quadro de influências e observações mútuas que muitos traficantes optam pela conversão religiosa. E se tornam, assim, "ex-bandidos".

O termo "ex-bandido" não costuma fazer referência aos indivíduos que cumpriram suas penas nas penitenciárias brasileiras. Daqueles que passaram pelo sistema penitenciário, costuma-se dizer que são "ex-presidiários" ou "ex-detentos" - termos cuja carga é extremamente negativa e que não fazem referência direta ao abandono das práticas criminais. Ao contrário, eles costumam reforçar o estigma de criminoso. Já o termo "ex-bandido" é utilizado amplamente nas igrejas pentecostais para se referir àqueles indivíduos que saíram da "vida do crime" por meio da conversão religiosa.

É importante destacar que, com este trabalho, não pretendo construir uma argumentação que "desmascare" a instrumentalidade da conversão, nem pretendo avaliar as intenções dos "bandidos" em relação à possibilidade da conversão. De fato, em contextos de violência, como já a pontaram autores como Leite (2009), "ser crente" pode ser uma forma de proteção individual. Os próprios pentecostais reconhecem que muitos criminosos "se escondem atrás da Bíblia" - referindo-se a indivíduos que simulam suas conversões com a finalidade de escapar de punições dentro da própria quadrilha ou de escapar da polícia².

O objetivo deste artigo é compreender o processo de construção de "ex-bandido" como categoria social. O material empírico é composto por um conjunto de dez entrevistas em profundidade ${ }^{3}$ com indivíduos que estavam envolvidos no comércio ilegal de drogas em diversas favelas cariocas e que se converteram ao pentecostalismo ${ }^{4}$, mais especificamente com pessoas pertencentes à Assembleia de Deus - que segundo Almeida (2006) é o grupo religioso que mais cresce nas periferias das grandes cidades brasileiras. Nessas conversas, os entrevistados falaram sobre a entrada e a experiência na "vida do crime", bem como sobre a conversão religiosa e a experiência como "ex-bandido". Com base em suas narrativas, procurarei analisar, de uma perspectiva com- 
preensiva, o processo de construção e de manuseamento das categorias "bandido" e "ex-bandido".

\section{"BANDIDO" COMO REPRESENTAÇÃO SOCIAL}

No início do século $X X$, o personagem identificado com o crime no Rio de Janeiro era o "malandro de morro". Este, como já apontaram alguns autores (Zaluar, 1985; Misse, 1999), era caracterizado pela aversão ao trabalho e por habilidades sociais que lhes permitiam viver às margens do mundo (burguês) do trabalho. Além disso, os "malandros" também eram caracterizados como personagens perigosos por dominarem técnicas de luta (geralmente a capoeira) e por portarem armas brancas (navalhas). Em A Máquina e a Revolta, Zaluar observa distinções entre o "malandro" e o "bandido", apontando para a violência como principal elemento de distinção entre os dois tipos sociais. De acordo com a antropóloga, com a emergência do tráfico de drogas (mais especificamente o de cocaína, no fim da década de 1970 e no início da de 1980) e, com ele, a introdução da arma de fogo, criaram-se as condições para que as representações coletivas em torno dos "personagens perigosos" fossem transformadas. Enquanto o "malandro" estava munido com suas habilidades, seja para a conversa, para a música, luta ou dança, o "bandido" firma a sua base identitária no uso da arma de fogo e na "disposição para matar". Violência, crime e drogas parecem fundir-se e constituir o solo sobre o qual se erige a representação social acerca do "bandi$\mathrm{do}^{\prime \prime}$.

Segundo Misse (1999), diferentes configurações sócio-históricas produzem diferentes representações sociais daqueles que são reconhecidos como criminosos. A partir de uma perspectiva macrossociológica, o autor identifica, com base em uma pesquisa realizada no Rio de Janeiro, tipos sociais distintos: o "malandro", das primeiras décadas do século XX; o "marginal", de meados do mesmo século, cuja especificidade está relacionada com a prática de assaltos a banco; e o "vagabundo", que está associado ao início do tráfico de cocaína nas favelas cariocas. Para Misse, tais categorias não consistem apenas em rótulos ou termos acusatórios, mas dizem respeito à representação social de uma "condição subjetiva". A isto, o autor chama sujeição criminal. Trata-se de um conjunto de marcas identitárias produzidas socialmente que podem ser reconhecidas como tipos de "subjetividade", de "personalidade" ou mesmo de "natureza". Nesse sentido, podemos dizer que "bandido" é uma representação coletiva construída historicamente e que está 
relacionada, sobretudo, ao contexto do comércio ilegal de drogas nas favelas cariocas.

Bourgois (1995), ao estudar o comércio ilegal de crack em um bairro pobre de Nova York, mostra-nos como a adesão às redes criminosas e a adesão ao que ele denomina como street culture não é apenas fruto de uma estrutura social opressiva. Ou seja, Bourgois procura, com base em sua etnografia, atacar a tese da desorganização social. Neste sentido, a adesão às redes criminosas não é vista como resultado de uma estrutura social "desorganizada", mas como uma estratégia dos atores para conseguirem atribuir status a posições sociais marginalizadas. Desse modo, na contramão da ideia de pensar a criminalidade como resultado de desorganização social e/ ou de uma estrutura social opressiva, Bourgois propõe pensá-la como organização e como estilo de vida - controverso, pois, ao mesmo tempo em que seria uma espécie de resistência ao "estilo de vida dominante", é também autodestrutivo. De acordo com o autor, é preciso atentar para o modo como os atores experimentam e vivenciam a estrutura social opressiva.

Utilizando uma abordagem semelhante, pretendo, a partir de então, compreender o tráfico de drogas e sua organização, suas relações sociais e suas implicações simbólicas, com o objetivo de entender não apenas o modo como a categoria "bandido" é socialmente construída nesses contextos, mas também observar como os atores a experimentam e a vivenciam. Assim, antes de traçar alguns comentários a respeito do processo de conversão de "bandidos", trarei alguns elementos que nos ajudarão a compreender melhor de que modo a categoria "bandido" é forjada e operacionalizada no contexto do comércio ilegal de drogas nas favelas cariocas. Em outras palavras, a ideia é enfatizar o modo como os atores sociais constroem essa categoria coletiva, bem como perceber as suas possibilidades de manuseamento, isto é, o modo como eles lidam com tais categorias contextualmente. Adiante, trarei alguns elementos empíricos para pensarmos quais os impactos que o modo como o tráfico de drogas se organizou no Rio de Janeiro têm sobre os indivíduos que com ele se envolvem. Masculinidade exacerbada, uso da violência e da arma de fogo e, sobretudo, "disposição para castigar" - características tão bem estudadas por autores como Alvito (2001); Barbosa (1997); Zaluar (1985) entre outros - são as principais componentes da categoria em questão. 


\section{CONSTRUÇÃO, MANUSEAMENTO E ASSIMILAÇÃO}

O tráfico de cocaína, mais especificamente, inaugura um tipo de organização do comércio ilegal de drogas e constrói um arranjo de relações sociais (interno e externo às quadrilhas) cujos elos são garantidos, em última instância, pelo uso da força, da arma de fogo. A organização do comércio ilegal de drogas, nas favelas cariocas, fundamenta-se em relações de amizade, confiança, relações comerciais, mas que são sempre garantidas pelo uso da força ${ }^{6}$. Não é por acaso que o "X9" (o delator) é uma figura extremamente odiada no "mundo do crime". A ele são reservados os castigos mais cruéis. Pois sempre que o "X9" age, ele sinaliza uma certa fraqueza dos elos de confiança que estruturam a quadrilha e a completa instabilidade das relativas ordem e paz. Até a própria polícia age de maneira cruel com os delatores: geralmente, depois de forçá-los a falar, ou mesmo quando eles falam por iniciativa própria (por vingança em relação a algum membro da quadrilha, por exemplo), os policiais os entregam ao bando. De modo geral, ele é assassinado e feito literalmente em pedacinhos ${ }^{7}$.

Zaluar (1985:151-152) descreve de forma bastante clara a articulação entre organização do comércio ilegal das drogas e a importância do recurso à violência para a funcionalidade do negócio. Segundo a autora,

como o tráfico é ilegal, não há nenhum meio jurídico de realizar a cobrança, e a lealdade pessoal não é suficiente para garantir o cumprimento do contrato. Quem o garante, no final das contas, é o revólver, usado sem contemplação em cima dos traidores. $\mathrm{O}$ vapor é aquele que recebe a droga no local e espera os fregueses. Ele é o 'homem de confiança' do traficante e deve prestar conta a ele do que for vendido e dos gastos para manter a neutralidade policial. O avião é o que vai até o freguês, ou melhor, o que 'aponta o freguês' para o vapor e, ao mesmo tempo, vigia a polícia. Dele, portanto, depende o vapor para avisá-lo da chegada de um freguês ou da polícia. Dele, uma traição pode ser fatal para o vapor. Sobre ele, o vapor mantém o poder também através do revólver, no final das contas. A dependência vital entre os elos dessa hierarquia e a consequente possibilidade de traição e engano, tanto no que diz respeito à neutralidade policial quanto ao pagamento neste rendoso comércio, torna necessária a coerção pela força das armas.

A ênfase nessa descrição recai sobre o caráter comercial das relações, sustentadas, em última análise, pelo uso da arma de fogo. Porém, tal organização do tráfico não se restringe só à relação entre "patrões e em- 
pregados" ou entre a quadrilha e a polícia; ela também atinge a "comunidade", a organização social da favela, impondo-se como "poder paralelo" (Leeds, 1998). A ordem na "comunidade", dessa forma, também é, se não garantida, ao menos realizada por meio do uso da arma de fogo. Assim, o tráfico de drogas é capaz de criar "leis", "julgar" os infratores e "puni-los". Isso é extremamente variável de favela para favela: depende, de maneira geral, da relação dos moradores com o tráfico, do carisma e da personalidade do "dono" e de contextos específicos (estar em "guerra" ou não, por exemplo). Mas, o ponto relevante aqui é: a articulação entre a organização do tráfico e a violência extrapola o limite dos conflitos (internos ou entre quadrilhas) e atinge a organização social da favela. Desse modo, não são apenas o traidor e o devedor que podem se tornar objetos da violência de traficantes, mas também qualquer pessoa que descumpra as regras: um marido que bate em sua mulher, um filho que agride a mãe, o estuprador, o ladrão que rouba na localidade etc. Os castigos variam de simples advertências, passando por coças - que podem ser públicas ou não -, podendo chegar à morte (o que não é raro).

Assim, a violência presente na organização do comércio ilegal de drogas, como instrumento que garante, em última instância, a funcionalidade do negócio, incorpora-se à própria organização social da "comunidade" e se torna, em muitos lugares, parte integrante do cotidiano. Mas, de acordo com o que ouvi de muitos entrevistados, tal violência não acontece de forma descontrolada, uma vez que aplicá-la sem o conhecimento e/ou consentimento do "dono" também pode implicar castigo. Obviamente, isso varia de acordo com diferentes situações e de acordo com a importância do infrator dentro da quadrilha ou dentro da favela (Barbosa, 1997). De maneira geral, funciona como me disse um dos entrevistados, Altair, ex-traficante, a respeito da "comunidade" onde mora: "lá ninguém mata sem ordem do dono".

Sem uma pesquisa empírica in loco não há como saber os limites desse tipo de afirmação. Mas, ainda assim, a fala de Altair nos sugere uma ideia importante: a violência do tráfico não é caótica. Ela acontece de acordo com regras estabelecidas pelos "bandidos" locais. Muitos entrevistados narraram, por exemplo, situações em que eram obrigados pelo "dono" a "tomar atitudes" (termo nativo utilizado para se referir à ação violenta). Ou tinham a obrigação de "tomar atitudes" devido a sua posição no tráfico. Aliás, este é um dos pontos importantes para se pensar "bandido" como representação social e como categoria nativa. 
"Bandido" é, entre outras coisas, aquele que tem "disposição para castigar". Desse modo, o envolvimento com práticas criminosas não produz, por si só, "bandidos". Ou seja, criminoso não é sinônimo de "bandido" - embora o contrário seja válido. Pensando nos mesmos moldes de Mauss (2003), acerca de sua teoria geral da magia, podemos dizer que, do mesmo modo que para o mágico há certas condições de possibilidade para a identificação com/assimilação da marca social, o "bandido" também precisa cumprir certos requisitos para ser considerado (e também reconhecer-se) como tal.

No início de minha pesquisa, algumas situações me fizeram perceber que, para falar sobre os "ex-bandidos", seria indispensável realizar uma reflexão mais cuidadosa acerca da categoria "bandido". Como em uma vez, quando eu fui apresentado a um homem que havia feito parte de uma quadrilha de traficantes em uma favela carioca. Eu disse a ele quais seriam as principais ideias da pesquisa e logo ele me alertou: “Então não sei se posso ajudar, não. Porque fui ladrão, traficante, fiz minhas besteiras por aí, mas bandido... bandido eu nunca fui, eu nunca fui de fazer ruindade com as pessoas, nunca fui uma pessoa violenta." Situações como esta me indicavam uma disjunção entre a prática de crimes e a assimilação da marca social, entre "estar no crime" e "ser bandido".

Para melhor compreendermos tais questões, trago um caso relativo a um traficante que não se reconhecia como "bandido". Aqui, ele será chamado de André. Ele dizia que, apesar de estar no tráfico, não era "bandido"; que ele não era como os outros. André atuou como soldado e gerente da maconha em uma favela do Rio de Janeiro. Certo dia, houve um assalto no morro e ele foi chamado para resolver a situação. Deixemos que ele nos conte sua história.

A senhora falou assim: Meu filho, não solta ele agora não porque se ele sair ele pode me pegar ali. Aí eu falei: Senhora, pode ir tranquila, pode ficar tranquila que ele vai resolver outra situação. Aí eu peguei e falei: Ó, você vai conversar com o cara [o dono] lá dentro lá, reza pro cara tá de bom humor pra poder só te dar uns tapas e te liberar. Falei assim pra ele. Aí ele pegou, entrou pra dentro do carro, pegou e fomos. Aí chegando no patrão lá, o cara era usado mesmo pelo diabo, era usado mesmo. Aí ele me chamou e perguntou: Qual foi? O que é que houve lá dentro? Aí eu falei, esse cara, morador lá de cima, cria do morro, e roubando morador lá na entrada da favela. Aí ele falou: Ah não, isso não. Aí ele falou assim: Já tô um tempão sem matar, esse eu vou pegar ele. Eu ainda 
tentei aliviar, falei: Pô, dá só uma coça nele, é cria do morro, daqui a pouco a família dele vai ficar procurando ele aí. Aí ele: Tá tranquilo. Aí pegou o maluco, e eu só ouvindo, e falou assim: Por causa de que tu roubou a moça na entrada da favela? Aí ele falou: Pô, é que eu sou viciado, pá. Aí ele: Ah é? Tu roubou ela porque você é viciado? Queria usar droga? Aí ele: Queria pô, eu uso. Aí ele: Então tu vai usar droga agora. Pegou, foi lá e mandou vir a droga pro cara. Eu até pensei que ele ia liberar o cara. O cara usou a droga. E ele: E você roubou ela mais por quê? Aí ele: Pô, porque eu tava com fome. Tava com fome? Toma aí comida. Comeu a comida e eu lá pensando né, o cara vai liberar. Daqui a pouco ele me chamou num canto assim: Ó, pode levar, pode levar pra matar, irmão. Pode levar que eu tô ligado legal que vai continuar roubando. Pode levar, não dá mole não. Aí eu peguei e... caraca. Peguei assim e: Vou levar mais alguém, valeu? Aí ele: Pode levar. Aí eu: Então já é. Chamei só os carniceiros. Falei assim: Vamos ali comigo ali. Peguei e fui. Levei. Era quatro e pouca já da manhã. Nós subimos de carro lá pra dentro de uma mata lá onde os caras matavam e ali desceu. Eu parei o carro mais pra baixo e falei: Leva ele lá em cima lá, leva ele lá em cima lá que eu vou parar o carro aqui. Pode ir pegando, ainda falei assim pros moleque, pode ir pegando, é com vocês mesmo. Vou deixar o carro aqui em baixo e vou ali pra arrumar a gasolina. Aí eu fui lá em baixo, dei um rolezinho de carro, escutei os tiros, depois voltei. Voltei e falei: E aí? Cadê o cara? Aí eles: Ué, tu não mandou matar o cara? Aí eu falei assim: Que é isso, mané!? Aí eu, disfarçando: Você não deixou eu dar nem um tiro, cara!? Pô, vocês é ruim mesmo, hein! Aí os caras: Pô, mas tu não falou nada, se eu soubesse eu deixava aí pra tu matar o cara. Então já é. Aí eu falei assim, ó: Enterra ele aí ó. Enterra ele aí que não tem gasolina não. Aí não dava pra queimar ele. Aí eu peguei pra mim mesmo e falei: Pô, me livrei de uma. (André, entrevista realizada em outubro de 2008)

Ele conta em outros momentos da entrevista que nunca havia sido uma pessoa violenta, apesar de "estar naquela vida". Questionei-o, perguntando como ele agia quando tinha que "tomar atitudes". Foi neste contexto que ele me contou esta história. Esta situação sugere que a "disposição para castigar" é uma componente fundamental de "bandido" como representação social. Esta situação é também bastante relevante para pensarmos os impactos simbólicos referentes à organização social do tráfico de drogas nas favelas cariocas.

A "armação" se deu por diversos motivos: 1) André afirma não ser como "os outros", não ser violento; 2) André conta em outros momen- 
tos da entrevista que sabia que era preciso agir assim: tanto para não perder o respeito e a "consideração" com os demais parceiros de quadrilha, quanto pela possibilidade de ser castigado pelo chefe caso este soubesse que ele não queria matar o ladrão que havia desrespeitado as leis do tráfico. Ou seja, André conhece as regras do jogo e sabe exatamente como um "bandido" deve agir. E, para agir corretamente, de acordo com a condição na qual se encontra, simula uma reação de descontentamento ao não participar do "serviço", como na situação acima descrita. Ele ainda justifica a não-participação ao seu "patrão":

E eu cheguei lá depois com os moleques de carro e cheguei pro cara e ele: E aí, qual foi? E eu falei: já foi! Os caras nem deixaram eu pegar o cara! E ele: E o que tu foi fazer? Eu falei: Pô, eu fui arrumar uma gasolina. Aí ele falou: Também só levou esses carniceiros aí, esses caras não deixam passar nada. A gente riu. Eu sempre metia uma dessa, escolhia os mais carniceiro, os mais ruim. (André, entrevista realizada em outubro de 2008)

Essa disposição para castigar parece compor parte importante das expectativas e obrigações (Goffman, 1981) relativas ao "bandido". Do "bandido" não se espera apenas o envolvimento com uma prática criminal, mas uma série de comportamentos, atitudes, modos de agir, sentir e pensar que compõe uma espécie de quadro de referência para o reconhecimento (e autorreconhecimento) da marca social. Para ser reconhecido como "bandido", André necessita exibir sua disposição para "tomar atitude contra vacilão". É importante frisar que tal disposição não é apenas uma expectativa dos demais em relação ao comportamento do "bandido", mas uma obrigação moral (Mauss, 2005). E esse status é reforçado tanto pela simulação da "atitude" quanto pela justificativa ao "patrão". Entretanto, os indivíduos são capazes de manusear as marcas sociais sem necessariamente assimilá-las como "verdades de si", como no caso de André.

Para nos ajudar a compreender melhor essa situação, trago para a discussão as ideias de Goffman $(1959 ; 1975 ; 1976)$ acerca da representação do self e do manuseamento da identidade deteriorada. Segundo o autor, o estigma pode ser manipulado por meio de técnicas de controle da informação, de encobrimento ou de acobertamento. Isso, de modo geral, evidencia (e reforça) a representação social da "normalidade", pois, de alguma forma, esta manipulação diz respeito à simulação de uma "normalidade" na qual o indivíduo estigmatizado não se encontra. Parece ser exatamente isso que André faz quando nos conta sua 
história. Ele, uma vez na condição de "bandido", precisava agir de determinada maneira: assassinar o ladrão que descumprira as leis locais, a mando do "patrão". Afinal de contas, ele era gerente do tráfico, um "bandido". É assim que devia agir. Porém, embora fosse esta a sua identidade virtual, ela, de acordo com ele, não correspondia à sua identidade real: ele não se reconhecia como um "bandido".

Goffman (1959) também utiliza as ideias de cenário, fachada e bastidor como ferramentas analíticas para pensar acerca das propriedades das relações sociais face a face. Com base nisso, o autor analisa as possibilidades de manuseamento de marcas sociais, isto é, a capacidade dos atores de lidar com as representações coletivas. Podemos dizer que André manuseia o espaço da fachada e simula a seus interlocutores uma ação condizente com a sua posição social (gerente do tráfico). Entretanto, nos bastidores, André não se reconhece como um "bandido"; é alguém que "não possui disposição para castigar". Seu estigma, neste caso, consiste em atuar como traficante, mas não querer punir violentamente alguém que, de acordo com as leis do tráfico, deveria ser castigado. Ele não quis agir de acordo com a posição que ocupava, de acordo com a condição em que se encontrava. Assim, ele simula uma situação na qual não estaria presente quando outros estivessem "fazendo o serviço". Quando retorna, simula uma insatisfação por não ter participado do assassinato. Desse modo, mesmo que André não se considere uma pessoa violenta, "ainda que estivesse no crime", sua atitude reforça o que seria o "normal" naquela situação.

Na medida em que André encobre sua falta de "disposição" para "tomar atitudes", atua como um desviante secreto (Becker, 2008). Para estar no crime sem "ser bandido", André se esforça em manusear sua fachada e esconder os bastidores - para poder preservar sua "moral" dentro da quadrilha. Apesar dessa possibilidade, há casos em que ocorre a assimilação subjetiva da representação social "bandido". Ou seja, há um reconhecimento de si mesmo como "bandido"; a marca social atinge a subjetividade do indivíduo e este a absorve como verdade de si. Nesses casos, a fronteira entre a fachada e o bastidor é desfeita na narrativa e o ator passa a se reconhecer como alguém "inteiramente criminoso", "de fato bandido".

Vejamos a história de William ${ }^{8}$. Nela, observaremos como a narrativa aponta para uma mudança de comportamento conforme o envolvimento gradual do indivíduo com o "movimento". Trata-se do reconhe- 
cimento, por parte do narrador, de um processo de "transformação do self". Na história de William, assim como na de André, veremos como, mesmo que o indivíduo esteja participando diretamente de uma atividade criminosa, ele não se percebe automaticamente como um "bandido". Tal transformação ocorre em determinada situação de violência vivenciada no contexto do tráfico de drogas. A narrativa de assimilação pode ser pensada como um "mito de origem do bandido" ou como um momento de "conversão" a partir do qual o indivíduo compreende a si mesmo com base em determinadas representações coletivas sobre o que é "ser bandido".

William nasceu e cresceu em uma favela na Baixada Fluminense. Ele nos conta que sua infância foi "como a de qualquer criança normal", pois ele sempre estudou e, embora sua família não fosse rica, sua mãe sempre batalhou muito, como proprietária de uma loja de roupas no próprio bairro, para dar boas condições de vida a seus filhos. Entretanto, ele estabeleceu relações de amizade com os rapazes da bocade-fumo próxima à sua casa. E aos poucos foi se envolvendo com o tráfico.

O envolvimento com o comércio ilegal de drogas e com os "bandidos" rendia a William uma certa fama no local. Para os outros, a vizinhança, ele era mais um "bandido", alguém que havia "perdido o rumo" e que era exatamente como os outros com quem andava. Mas o próprio narrador não se percebia como um "bandido". Não se trata aqui do desviante falsamente acusado (Becker, 2008) ${ }^{9}$. William é um praticante de crimes, é um indivíduo que adota práticas socialmente rotuladas como criminosas - ele faz parte da quadrilha. E reconhece isso em sua narrativa. Porém, quando diz que não é "bandido", não são tais práticas que estão em jogo, mas sua "subjetividade". O que William nos conta sobre isso também é extremamente interessante para pensarmos como o indivíduo pode lidar com a identidade sem necessariamente assimilá-la. Deixemos que ele fale mais de sua história:

Aqui eu não tinha muito serviço ainda, até porque eu não tinha muita experiência. E as pessoas me viam assim: ele cresceu, tá andando com os caras e agora tá matando as pessoas. Essa era a visão deles. A minha visão, no meu ponto de vista, era assim: caramba, agora eu sou o cara. Os outros garotos da minha idade tavam jogando bola, brincando de outras paradas e na minha visão eu tava acima deles. Mas até então nem tinha parado de estudar e era tudo normal, normal. Pra você ver como a coisa assim na minha cabeça não era tão séria. Não tinha pegado a coisa 
legal. Na escola então era uma maravilha. Tinha um colega, que até então eu estudava normal, só tirava nota boa e tal, e na hora do recreio a gente embarreirava o banheiro. Só entrava quem a gente deixava. E como eles tinham uma visão de: Pô, William tá com os caras, ele mata também, William é ruim... Só que eu não me via assim, eu era mais um zoando no colégio. (William, entrevista realizada em setembro de 2008)

William lidava positivamente com a "fama" e com o estereótipo que lhe era atribuído, ao mesmo tempo em que afirma ter consciência de que não era assim que ele mesmo se via. Mesmo lidando positivamente com uma identidade virtual, para usar os termos de Goffman (1975), de "bandido" (diziam sobre ele: "Anda com bandido, mata como bandido e é ruim como bandido"), ele não a assimilava como uma identidade real (ele não se reconhecia como um "bandido"). Como ele conta: "A coisa não era tão séria ainda". Tudo corria de maneira bastante segura e a "carreira" de William se desenvolvia sem maiores problemas. Até o momento em que algo acontece: ele se vê cada vez mais imerso no grupo e é impelido a adotar certas "atitudes", não somente por estar envolvido no comércio ilegal das drogas, mas por fazer parte de outras ações.

Até o momento em que acontece um problema aqui e aí eu ia me dar conta do que tava acontecendo de verdade. Tinha um cara que fazia bandalha aqui dentro e ele errou com os caras aí e até hoje eu não sei o que foi. Só que os caras me chamaram e: Ó, a gente vai pegar o cara hoje e você vai fazer o seguinte: você vai chamar fulana, vai mandar ela dar mole pro cara, pra ela levar ele lá pro campo pra gente poder matar ele. Então tudo bem. E quando eu saí dali minha mão tava tremendo. E no meio do caminho eu fiquei pensando no que tava acontecendo e falei: Rapá, os cara vão matar o cara. E eu tô... e eu tenho parte nisso. Só que o cara, ele sempre quis pegar essa menina e nunca conseguiu. Aí vem a mulher dizendo que quer sair com ele e ele foi e desconfiou disso. Só que ela queria sair com ele pra um lugar que ela escolhesse e não ele. Ele se preocupou com isso e não foi. Passou uns três, quatro dias o cara virou pra minha mãe e falou: Ó, colocaram uma carta dentro do meu carro falando que os cara tava querendo me matar aqui dentro. Pô, conversa com teu filho e tal; pô fiz nada pra eles, não sei quê. Aí minha mãe falou: Tá bom. E eu não fui interceder por ele, fui falar com os caras que ele já tava sabendo disso. Só que aí veio acontecer uma coisa: os próprios amigos meus acharam que fui eu que fiz isso, que eu que falei com o cara, que não tinha nada de história de carta não. Aí teve uma festa de 
rua ali em cima perto da escola, e eles tavam armando pra me matar. Aí chegou o pai da minha irmã, não é meu pai, é pai dela, e chegou e falou assim: Ó, os cara tão ali na linha do trem esperando a boa pra te matar. Tão querendo me matar? Então tá bom. Aí eu cheguei pro meu primo e falei: Ó, os cara tão querendo me matar aí, preciso de uma arma porque vou ter que tomar uma atitude. Aí eu assumi a vera [de verdade], aí eu tive que mudar de opinião. Aí que eu fui entender que não adianta ser o bonzinho da história. Tem que ser um cara ruim mesmo. Ou você se transforma num bandido ou você sai fora. Não fica porque certamente você vai morrer. Isso aí é certo. Aí eu tive que tomar uma atitude séria. Coisa que eu não fazia: andar armado de dia, eu já tava andando; já tava tomando atitude contra outras pessoas que eram meus amigos, tipo assim: ser mais grosso, mais sério, coisas que eu não era, entendeu? Eu era muito brincalhão. Notaram a diferença, se afastaram de mim. Até que eu comecei a puxar uns caras pra mim. Montar um bonde meu. Eu fiz isso. (William, entrevista realizada em setembro de 2008)

William assimila subjetivamente, como um habitus, a "lógica do ferro" (Zaluar, 1985). Como ele mesmo nos conta, para os outros ele já era esse "bandido". Essa situação é importante, porque é nesse momento que ele assume isso para si mesmo, descrevendo como "se tornou um bandido". Esse momento da narrativa pode ser caracterizado como um momento de "conversão". Trata-se de um ponto importante na narrativa que nos remete à ideia de construção de uma "verdade de si". E "tornar-se bandido" significa, em linhas gerais, de acordo com a história de William, o uso mais intenso da arma de fogo e a mudança de comportamento, tendendo a uma forma de agir mais agressiva e violenta, com "disposição para tomar atitudes".

É na relação com os demais membros da quadrilha, e ao experimentar determinadas situações, que William se constrói como "bandido". A assimilação subjetiva da marca social - a construção da verdade de si se dá de modo relacional (Mason, 2007; Pollak e Schiltz, 1991). É interessante também observarmos que a assimilação da identidade virtual que William já possuía se dá de maneira involuntária, no sentido de que isso acontece dentro de um episódio em sua narrativa em que ele é acusado de traição e, para se defender, "torna-se um bandido". Ou seja: a assimilação dessa identidade não consistia em um plano ou projeto individual10: ele nos conta que "não queria ser bandido" e que "não gostava da violência deles". Entretanto, uma vez no grupo, sujeito a situações de desconfiança, termina, assim, assumindo uma identi- 
dade de "bandido", incorporando a sujeição criminal. Pois, nas palavras dele: "Ou você vira um bandido ou você sai fora. Porque senão você morre".

Trabalharei precisamente com as narrativas de conversão religiosa de pessoas que assimilaram subjetivamente a marca social "bandido". A ideia é mostrar como o discurso religioso oferece uma chave simbólica com base na qual o indivíduo interpreta sua "condição de bandido" (sua sujeição criminal) e, a partir disso, procura transformar-se como sujeito - vivenciando um outro processo de construção de uma verdade de si.

\section{A CONVERSÃO DE "BANDIDOS” AO PENTECOSTALISMO}

Segundo os pentecostais, há uma batalha espiritual na qual os homens atuam a favor de Deus ou do Diabo: o "exército de Deus" age tentando libertar os homens do Diabo, por meio da conversão; os homens que pertencem ao "exército do Demônio" agem visando a perdição dos "santos", tentando corrompê-los, enganá-los, contaminá-los. Os traficantes são vistos pelos pentecostais como parte do "exército do Demônio" e como indivíduos que agem "influenciados pelo mal". São almas que precisam ser salvas pela conversão. Com base nessa teologia da batalha espiritual (Mariz, 1999), os pentecostais compreendem as ações que se desenrolam no mundo - por meio dela tudo o que acontece adquire algum sentido. Essa leitura teológica do mundo fornece a esse grupo religioso elementos para elaborar uma espécie de teoria nativa a respeito do crime e do criminoso.

Para os pentecostais, há uma correlação entre mal e crime, entre o Diabo (ou os "espíritos malignos") e os criminosos. Estas "forças do mal" quase sempre são associadas a divindades das religiões afro-brasileiras. Esta associação não é realizada exclusivamente pelos pentecostais, nem mesmo consiste em uma novidade. Outros autores (Maggie, 1992; Contins e Goldman, 1983) já apontaram para as associações construídas culturalmente que envolvem crime, mal e religiosidade de matriz africana. Contudo, tal correlação é fundamental na teoria nativa sobre o "bandido". Segundo Birman (1997:72),

os espíritos mais frequentemente mencionados por estes religiosos são aqueles que reconhecidamente "pertencem" ao campo maléfico, na classificação dada pelos cultos de possessão. As referências mais fre- 
quentes, portanto, são aquelas que dizem respeito aos exus mais facilmente associados a trabalhos pesados, que muitas vezes envolvem comportamentos claramente transgressores, como roubar e matar. Onde tem roubo e morte, não é difícil imaginar a presença de um exu Tranca-Rua, de um exu Caveira, especialistas no panteão reconstruídos pelo neopentecostalismo como os mais perigosos, capazes de levar as pessoas, sob seus poderes a cometer graves crimes. Da mesma forma, onde existe conflito, no casamento, ou na separação, tem-se a presença de pomba-giras, espírito relacionado à transgressão sexual e também à produção de conflito entre casais. Em casos de alcoolismo, os responsáveis são os exus malandros, como o Zé Pelintra.

O discurso que associa, de maneira geral, crime, malignidade e entidades das religiões afrobrasileiras pode se tornar tão forte que muitos "bandidos" chegam a assumir identidades associadas ao que é considerado maligno. No filme Cidade de Deus (2003), inspirado no livro de Paulo Lins (1997), a transformação de Dadinho em Zé Pequeno é mediada exatamente pela consulta a um pai-de-santo. É depois desse encontro que Dadinho se torna Zé Pequeno e se consolida como um "bandido", representado como violento e perigoso. De acordo com Zaluar (1997:117), há um “discurso que demoniza o criminoso a tal ponto, que não se trataria mais de bandidos ou de indivíduos identificados como desviantes, com a desordem e com o descontrole social". Segundo a autora, "muitos são vistos como a encarnação de entidades diabólicas a ameaçar o reino de Deus. Dessa forma, os próprios bandidos, identificados pessoal e profundamente com essa encarnação do mal, reinterpretam a sua saga por um pacto simbólico com ele" (Zaluar, 1997:116).

A partir dessas considerações, a seguinte hipótese surge: se a sujeição criminal pode ser representada como algo de ordem sobrenatural, ou seja, se o "bandido" tem sua conduta desviante justificada pela "influência do Diabo na sua vida" e, no limite, uma identificação com ele, então a conversão religiosa poderia desconstruir o "sujeito-em-relação-com-o-mal", conter o mal que o influencia e, consequentemente, "transformar" o sujeito criminal, dando origem ao "ex-bandido". Entretanto, esta possível "transformação" não ocorre de maneira tão simples. Ela é mediada por uma série de rituais, "exorcismos", "profecias", "revelações", aprendizado de novas técnicas corporais etc., que constituem um complexo processo de subjetivação (Foucault, 2006). 


\section{RESSIGNIFICANDO 0 MITO DE ORIGEM DO "BANDIDO" - 0 CASO DE ALEX}

Aqui poderemos observar como o indivíduo, em sua narrativa, desloca a forma de compreensão de sua "condição subjetiva" de "bandido". De modo homólogo às mulheres estudadas por Mason (2007), que, ao se "tornarem feministas", deslocavam suas formas de compreensão acerca de sua própria condição de mulher com base na "teoria nativa" (feminista) e, a partir disso, reelaboravam a sua existência como um "ser", ou seja, produziam uma nova verdade de si, os "ex-bandidos", com base na "teoria nativa" (religiosa) sobre o criminoso, reinterpretam a sua condição de "bandido" e modificam a forma como compreendem a si mesmos. Vejamos o caso de Alex:

Eu nasci numa periferia chamada Parque Imperador, lá no Rio. Tive uma infância pobre mesmo, sabe? Perdi minha mãe com um ano de idade. Só sei que era negra. Meus irmãos que me contavam alguma coisa sobre ela. Sou o caçula de uma família de cinco irmãos, três homens e duas mulheres. Minha juventude foi difícil à beça. Pai? Foi embora de casa quando eu tinha cinco anos. Uma das minhas irmãs tinha catorze anos na época e meu irmão mais velho, que tinha quinze (inclusive ele hoje é pastor), tiveram que abandonar os estudos cedo pra poder sustentar a gente. Vida de miséria, irmão. Morava em barraco de pau-a-pique. E digo pra você: até cinco anos foi o pior período da minha vida. Aí a gente começamos a evoluir depois... nessa época a cocaína tava chegando ainda. A gente comia quando tinha. Tinha uma feira, e eles esperavam a feira terminar pra poder pegar o resto que sobrava. E quando eu completei uma idade que a gente começa a entender o que é certo e o que é errado, comecei a sentir uma certa revolta, porque eu via assim... que crianças da minha idade que cresceram com seus pais, mesmo lá no Parque Imperador, tinha aquele que podia proporcionar um carinho, um afeto e um alimento. E a gente nunca tivemos. Vida sofrida. Brinquedo, então? Nem se fala. Quando eu ganhei meu primeiro carrinho, parecia que eu tinha ganhado o mundo. (Alex, entrevista realizada em março de 2008)

Este trecho de entrevista alude à pobreza e à miséria como fatores importantes para explicar a entrada do indivíduo na "vida do crime". Segundo o entrevistado, este é o ponto de partida, o chão sobre o qual se erige a revolta que o leva a praticar crimes. A revolta (estudada por Alba Zaluar), por sua vez, não aparece em relação direta com a situa- 
ção de pobreza. Para além de uma ideia genérica relativa ao pertencimento a uma "comunidade pobre", há também, na narrativa, a alusão a um contexto de desigualdade dentro da própria favela em que Alex fora criado. Eé a partir da constatação desse fato que a revolta torna-se presente nele. Mas isso não quer dizer que haja uma ligação causal entre desigualdade e entrada para o crime.

Então a primeira coisa que me veio foi usar cocaína, aos treze anos. Aí eu comecei a fazer alguns furtos pra poder comprar droga e manter o vício. Nessa época o dono era o Nandão. E eu comecei a andar com eles. Comprava quentinha, manda o menor. Começamos como office boy do crime. Ô menor, vai lá embaixo comprar bermuda e chinelo pra mim, toma aqui, compra pra você também. Comprava só de marca. Todo mundo queria usar. Katina surf, redley, alternativa. (Alex, entrevista realizada em março de 2008)

A prática de crimes não aparece diretamente ligada à subjetividade de Alex. Ele identifica na pobreza, na desigualdade local e na "desestruturação familiar" (a mãe morreu quando ele ainda era muito pequeno e o pai logo foi embora de casa) aquilo que lhe motivaria a entrar para o crime. Aqui o que está em jogo é a justificação de uma prática criminal. Porém, a ligação entre, digamos, problemas sociais, familiares e a prática criminal é mediada pelo "vício" em cocaína. A ligação feita pelo entrevistado é a seguinte: devido a esses problemas ele acaba viciado em cocaína e, para poder consumir a droga, começa a fazer pequenos furtos e pequenos trabalhos para os traficantes. Até então, não há nenhuma referência a uma suposta subjetividade peculiar de criminoso.

E, nesse período, esse meu irmão que hoje é pastor era viciado, e eu comecei a fornecer drogas pra ele. No tráfico só eu me envolvi. Tinha irmão viciado, mas não traficante. Foi descoberto por um integrante da facção rival que eu fazia parte (fazia endolação, às vezes era lá em casa, guardava armas, droga). Eu era usuário e o jeito que eu conseguia era ceder pra ele um espaço dentro da minha casa. Era uma pequena fábrica. Quando eles descobriram, eu comecei a perder pequenos espaços no morro. Eu não podia frequentar todos os lugares. Tinha ameaça de morte. Disparavam arma na gente. Pra eles eu já era traficante do Terceiro Comando. Eu comecei a limitar, não podia sair daquele espaço, só podia estar onde eles estavam. Tem um lugar chamado Seu Lili, uma faixa de gaza. E eu não podia atravessar pra lá. E minha irmã morava do outro lado, eu não podia mais ir. E aí quando eu fiz quinze anos eu recebi a primeira proposta formal. Nandão me chamou: 'Ô Caveirinha, os 
caras do CV [Comando Vermelho] já sabem que você tá fechando com a gente, você não pode mais estar circulando em algumas áreas do morro, tão querendo te matar. Por que você não forma com a gente? Você já é bandido mesmo'. Eu tinha receio pela minha família, de alguém fazer algo com a minha família. Aí eu recusei. Porque eu tenho família etc.. Mas aí ele disse: 'Mas pra morrer por uma causa que não é a sua, é melhor morrer pela que é a sua'. Aí eu comecei a me envolver. (Alex, entrevista realizada em março de 2008)

Alex nem mesmo se considerava um traficante. Isso acontece aos poucos. O envolvimento dele começa com o vício em cocaína, que, conforme a narrativa, leva-o para mais fundo nas bocas-de-fumo. Ou melhor, para conseguir acesso à droga, permite que a boca vá até a sua casa: como ele conta, durante algum tempo a "endolação" foi feita lá. E diante deste comprometimento público com o tráfico e, por consequência, com uma facção determinada, o Terceiro Comando, Alex tem sua liberdade espacial limitada, pois os "alemão do CV", já sabendo que ele "tinha fechado" com o "TC", passam a persegui-lo como inimigo. Daí vem o convite formal de Nandão para Alex. Ele titubeia por causa da família, mas aceita. Ganha o apelido de Caveirinha. "Transforma-se em um bandido".

A sujeição criminal lhe é revelada pelo próprio "dono do morro" em duas sentenças: 1) "[...] os caras do CV já sabem que você tá fechando com a gente, você não pode mais estar circulando em algumas áreas do morro, tão querendo te matar. Por que você não forma com a gente?". O comprometimento público de Alex com o tráfico transforma-o em "bandido". E para completar a sentença, o dono lhe aponta o crime dentro dele, atingindo sua subjetividade: "Você já é bandido mesmo". A partir de agora ele estava no "caminho sem volta", pois ele era assim, um "bandido". Já não interessava o que ele fazia, mas sim quem ele era. A sua preocupação em entrar no tráfico e envergonhar a sua família não poderia ser um motivo de impedimento, pois aquilo já fazia parte dele e ele não poderia escapar. É então que Nandão lhe aplica a segunda sentença: 2) "Mas aí ele disse: 'Mas pra morrer por uma causa que não é a sua, é melhor morrer pela que é a sua' , aí eu comecei a me envolver". Não foi porque Alex entrou para o tráfico de drogas que ele se tornou um "bandido". Ao contrário, por já se ver como um "bandido" que ele topou a proposta de Nandão. Era a "causa" dele. E já que ele era um "bandido", não adiantava ficar de fora e lutar por uma causa que não era dele (a família dele) e acabar morrendo (como o "bandido" que ele 
realmente era, segundo a narrativa) por ela; era melhor "entrar de vez", assumir a "causa dele" (ele próprio, a sua subjetividade, a sua sujeição criminal) e morrer por ela justamente. A atenção é, a partir de então, deslocada da prática para o praticante, da ação rotulada como criminosa para o agente que é reconhecido como portador de uma subjetividade intrinsecamente criminosa.

Como ele já havia contado anteriormente, dos cinco irmãos, ele havia sido o único envolvido com o tráfico de drogas. Ele tivera irmãos "viciados", mas traficante só ele. Depois de anos na "vida louca" do tráfico em vários morros do Rio, Alex vem a saber de uma história importante, que ainda não lhe tinha sido contada e que fora fundamental para a sua conversão religiosa. Vamos a ela:

Meus pais eram macumbeiros. Minha irmã mais velha chegou a seguir. Quando eu tinha sete meses de gestação (meu irmão me contou isso depois de muito tempo), minha mãe teve uma consulta com uma entidade: Zé Pelintra. E ela fez um pacto com ele. Ela queria algo e ele disse pra ela que daria, mas ele queria algo em troca. E nesse dia ela ofereceu a mim. Eu te ofereço meu filho se você me der o que eu quero. Houve esse pacto. Eu não sei o que houve, mas foi feito, pacto de sangue. Teve todo um ritual, ela se sangrou, bebeu sangue de animal, teve todo um ritual macabro. Fui oferecido em troca. E na outra semana eu ia completar dezesseis anos. E foi a pior experiência da minha vida. Teve baile funk no morro, soltaram balão, tinha traficantes de outros morros. Só que nesse dia, já até morreu ela, a Rosa, ela incorporava esse demônio, essa entidade. Ela usava com a gente. E nesse dia ela incorporou em casa e mandou me chamar. Eu fui lá. E foi quando eu descobri que minha mãe tinha feito esse pacto. Algumas pessoas olhavam pros meus irmãos e perguntavam: Poxa, por que é que só esse menino foi levado pra esse lado? O Adailton [irmão mais velho de Alex], todo mundo sabia que ele usava droga, mas ele era trabalhador, todos eles eram. Só o Alex que foi levado pra esse lado de ser traficante". (Alex, entrevista realizada em março de 2008)

De acordo com a narrativa, por causa da ligação da sua mãe com a "macumba", mas mais precisamente por causa do pacto que ela fez com Zé Pelintra, Alex acabou se tornando traficante, um "bandido". Interessante notar que a entidade em questão é identificada e caracterizada como "malandro", tipo social que, na primeira metade do século XX, era também uma categoria de acusação: criminoso. Como nos mostram Misse (1999) e Zaluar (1985), o "malandro", diferentemente do 
"vagabundo", utilizava habilidades pessoais e só raramente a violência, para levar uma "boa vida" sem precisar "dar duro no trabalho". No processo de acumulação social da violência na sujeição criminal (Misse, 1999), o "malandro" é metamorfoseado em "marginal" e, mais recentemente, em "vagabundo" - acumulando diferentes características, sendo a mais importante delas o comportamento violento. Nada mais (sócio)lógico, portanto, que exatamente uma entidade identificada com o "mundo do crime" ser responsabilizada por Alex por sua sujeição criminal.

A partir de então, nosso personagem está munido simbolicamente para compreender o porquê de ser como é, um "bandido". Sua suposta subjetividade peculiar, criminosa, sua sujeição criminal tem uma causa primeira, uma origem: é o Mal, o Diabo, o Zé Pelintra. Alex foi oferecido a ele ainda no ventre de sua mãe. Ali mesmo, quando era apenas um feto, não tinha consciência, "não se entendia por gente ainda", foi "contaminado pelo Mal". Nenhum de seus irmãos se tornou traficante. Todos estavam expostos às mesmas condições de pobreza e miséria. Todos sofriam com a desigualdade local. Por que Alex? Por que somente ele? Para Alex, só poderia haver algo de errado com ele. Um dos irmãos inclusive era viciado em cocaína (como ele) e mesmo assim não entrou para o tráfico. E vale lembrar que a cocaína é apontada em sua fala como a principal ligação entre a revolta e sua entrada para o crime. Mas só Alex tinha essa "sina", só ele havia sido "contaminado com o Mal" e, por isso, só ele estava condenado à vida de traficante, a ser um "bandido".

A reinterpretação do rapaz com base no discurso pentecostal aponta de uma outra perspectiva, religiosa, a sua sujeição criminal. Em um primeiro momento, ele se envolve com o tráfico por conta da pobreza, da desigualdade, da falta de carinho, do vício em cocaína e da revolta. É uma condição social que o leva a uma prática rotulada como desviante. É sua ação que está em jogo. Mas, a partir do momento em que ele se compromete mais profundamente com o tráfico, vê-se como um "bandido" - seu "mito de origem". Aqui o discurso se inverte: a partir de então não é mais a ação que define a condição de criminoso, mas a condição de criminoso que justifica, explica e define sua ação. E por meio do discurso religioso Alex pode enxergar claramente sua sujeição. Sua subjetividade tinha íntima e histórica ligação com o "mal do crime", o Zé Pelintra. Era por isso que "ele era assim", que ele "era um traficante violento". A partir do momento que pode explicar a sua subjetividade 
peculiar, pode, por conseguinte, explicar sua ação e sua prática criminosa. E a partir dos instrumentos simbólicos e discursivos que o pentecostalismo lhe oferece, ele pode explicar e compreender essa "subjetividade peculiar" e entender por que agia da maneira como agia. Tal leitura da sujeição criminal, de alguma forma, oferece a Alex a possibilidade de uma reelaboração de si mesmo - filtrada pela conversão religiosa.

Como já ensinara Mauss (2003), a crença nas representações é que produz a eficácia dos atos mágicos. Contudo, a releitura do "mito de origem" a partir de uma perspectiva religiosa não é suficiente, não produz automaticamente o "ex-bandido". É bastante evidente nas narrativas que a crença na "motivação sobrenatural" do "bandido" não é o que marca a conversão. A adesão a esta crença pode ser anterior (e geralmente é) à conversão. Os "ex-bandidos" se constituem em suas relações cotidianas, com base em um conjunto de práticas orientadas por um discurso religioso, visando uma espécie de "metamorfose subjetiva", na qual de "bandido" se passa a "ex-bandido". A conversão, nesse sentido, não diz respeito apenas à adoção de valores e crenças, mas a um processo constante de elaboração de si mesmo (Mason, 2007).

\section{CONSTRUINDO UMA NOVA VERDADE DE SI}

Eu não tinha um coração de carne, eu tinha um coração de pedra. O coração de pedra se transforma em coração de carne. Eu tinha um coração de pedra, um coração terrível. Eu fui criado selvagemente. (Ricardo, entrevista realizada em março de 2008)

Essa é uma fala de Ricardo, que foi traficante em uma favela carioca e hoje é membro de uma Assembleia de Deus. A metáfora ${ }^{11}$ diz respeito a uma representação da "natureza" do indivíduo. O traficante truculento e autoritário, com disposição para matar e sem medo da morte, precisa desaparecer. Alex, por exemplo, falava da postura do traficante: "O coração dele não corresponde a esse negócio de 'Pô, tem que ser bonzinho', sabe?" A ideia em jogo é a de que o "bandido" possui um "coração de pedra" - ou seja, a metáfora nos sugere que a marca social "bandido" é reconhecida como parte integrante de seu corpo, de sua subjetividade. E é exatamente a transformação dessa subjetividade reconhecida como criminosa que está em jogo na conversão - o "coração de pedra" deve ser transformado em "coração de carne". 
Como nos mostram autores como Mason (2007), Pollak e Schiltz (1991), a construção de si não consiste em algo de dimensão puramente individual, mas dialoga a todo momento com determinados marcos coletivos de identidade. A reconstrução de si, no caso dos "ex-bandidos", é permeada todo o tempo por dois marcos identitários: "bandido" e "crente". As narrativas apresentam uma espécie de "metamorfose subjetiva" (e física, ainda que metaforicamente) em que é a "natureza" do sujeito que está em jogo. Trata-se de uma "reforma do sujeito" - uma reconstrução radical de si que se baseia em uma reconstrução radical de suas relações com o mundo (Pollak e Schiltz, 1991).

Eu até entendo que a pessoa duvide, é normal que fique surpresa. Algumas nem criticam por criticar, criticam porque ficam surpresas. Hoje você vê o camarada de arma na mão e amanhã dentro da igreja, levantando a mão, dando glória a Deus, completamente diferente. Diferente no modo de se vestir, no modo de falar. Porque o traficante, você sabe que ele tem as suas gírias, o jeito de corpo, o jeito de molejo, um suingue diferente, até o modo de falar, um gesto de ficar em pé e tal. E quando eu me converti foi uma luta pra perder isso. Foi uma luta, uma luta. O que eu fazia, por exemplo, se eu tivesse com um martelo na mão é como se eu tivesse com uma arma. Se eu tivesse com um pedaço de madeira nas mãos é como se eu pegasse numa arma. Até a Bíblia, quando eu pensava que não, ela tava nesse sentido, como se eu tivesse pegando o gatilho de uma arma, como se eu tivesse engatilhando uma arma. Então foi uma luta pra eu perder estes tipos de manias que o tráfico, ele dá pro camarada que tá lá. Esses trejeitos. Às vezes a gente tava conversando com alguém assim e começava a sair uma gíria, dois, três, quatro... Mas a gente começamos a lidar com outras pessoas, até pessoas mais intelectual, pessoas com mais estudo. E a gente fomos aprendendo mais um pouquinho. Porque o evangelho é mudança. Porque o poder do evangelho, ele transforma e muda. É uma mudança em todos os sentidos. De pensamento, de gestos, de hábitos. (Alex, entrevista realizada em março de 2008)

De acordo com Goffman (1981), as formas de falar também dialogam constantemente com as marcas sociais: reconhecem-se coletividades nas formas de falar dos indivíduos. Isso aparece na preocupação de Alex com as gírias. De acordo com sua narrativa, "gíria é coisa de bandido", é algo que poderia caracterizá-lo como tal. É fundamental para o convertido aprender as maneiras de se comunicar que são próprias do grupo que lhe fornece os elementos para a sua reconstrução biográ- 
fica. A inserção na nova rede de relações que a conversão e a filiação a uma igreja oferecem parece ser importante no processo de mudança de habitus do "bandido". Nesse trecho de entrevista, Alex destaca a importância da convivência com outras pessoas não ligadas ao tráfico nesse processo de subjetivação do discurso pentecostal, de aprendizagem (do novo habitus pentecostal) e esquecimento (do habitus que caracteriza o sujeito criminal como "bandido"). As mudanças apontadas por ele são minimamente corporais: maneira de andar, de falar, maneira como pega um martelo, um pedaço de madeira, a própria Bíblia. Novas técnicas de uso do corpo precisam ser internalizadas. O corpo aparece como o lugar da verdade, como espaço de escolhas políticas, estéticas e religiosas; o corpo aparece como lugar de destaque para a assimilação da identidade coletiva como verdade de si e como chave simbólica para falar de si (Goffman, 1976).

Entretanto, a conversão religiosa não impede a possibilidade de que o "ex-bandido" retorne à sua condição subjetiva anterior. Há uma preocupação constante por parte do "ex-bandido": ele reconhece que sua condição pode ser bastante instável e que certas ações podem devolver-lhe a sujeição criminal. O processo de transformação que age sobre a "natureza do bandido", da perspectiva pentecostal, nunca se dá por completo. Há sempre que ser "vigilante". O indivíduo está sempre em "luta contra ele mesmo", contra a sua "natureza", sempre tentando domá-la. E, de acordo com a teologia da batalha espiritual, há a possibilidade de o "Diabo tramar para recuperar aqueles que ele perdeu": qualquer descuido do convertido pode fazer com que a sua natureza de "bandido" venha a prevalecer. Vejamos o caso de Eduardo:

Isso que eu vou te contar agora não tem muito tempo não. O homem me chamou ali pra trabalhar num terreno, pra limpar um terreno ali. Aí depois que eu limpei o terreno, ele disse que não tinha nada a ver, que o terreno não era dele. Que ele não ia pagar. Aí eu falei pra ele: Que isso, rapaz? Você me conhece? Você sabe do que eu sou capaz? Você perdeu a noção do perigo, rapaz? Aquilo foi uma armação do Diabo tremenda. Aí eu pensei: Não é nada disso não, nós somos novas criaturas. (Eduardo, entrevista realizada em outubro de 2008)

A condição de crente do "ex-bandido" está sempre ameaçada. Ele é uma figura ambivalente: ainda que "crente", ele pode, a qualquer momento, ter acesso a um outro registro identitário, o de "bandido". Suas experiências no mundo do crime fazem do "ex-bandido" alguém que habita uma condição especial: é possível que ele acesse as técnicas e 
práticas que aprendeu em sua experiência anterior. O que Eduardo aciona nesta situação é algo muito semelhante ao "Você sabe com quem está falando?", estudado por Roberto DaMatta (1990). Este bordão diz respeito a uma ambivalência do social, ao duplo ordenamento que caracteriza o dilema brasileiro: uma ordem social hierárquica e outra individualista. O "ex-bandido", em nosso caso, aparece como um tipo social ambivalente: sua trajetória é marcada pela experiência em distintos espaços - o crime e a igreja. Mesmo após a conversão e estando fora das atividades criminosas, o indivíduo pode recorrer à sua sujeição criminal. Porém, como pentecostal, o "ex-bandido" deve manter total controle sobre a possibilidade de acessar os registros que aludam à sua condição anterior. Há que se ter, a todo o momento, cuidado com os modos de falar, de se vestir, de andar, de se relacionar com os demais.

Essa "consciência do risco", em certos momentos, até mesmo dificultou a produção de entrevistas. $\mathrm{O}$ acesso à memória, por si só, era algo perigoso para o "ex-bandido". De forma um pouco distinta do que nos mostra Pollak e Schiltz (1991), aqui a memória não é somente construída com base no presente, mas também é capaz de afetá-lo. Ou seja, a identidade social não apenas permite ao indivíduo "produzir sua memória" (como um lugar a partir do qual o indivíduo seleciona o que deve ser lembrado, bem como o que deve ser esquecido), mas também pode ser influenciada por ela. Aqui, a memória não aparece somente como produto de uma condição social atual, mas como agente em potencial. Como me diziam os protagonistas deste trabalho, eles deviam falar de suas experiências sempre com o cuidado de enfatizar as "maravilhas que Deus fez", sempre enfatizando a "transformação". Para os "ex-bandidos", acessar a memória é algo que deve ser feito com extremo cuidado: nunca se sabe onde poderá se encontrar uma "armadilha demoníaca".

O "ex-bandido" experimenta o risco e a construção permanente do pertencimento a uma identidade coletiva de forma bastante intensa, uma vez que ele a todo o momento deve "ser nova criatura". O risco, inerente a qualquer processo de identificação - pois, como nos apontam autores como Becker (2008) e Goffman (1959), é nas relações sociais que se constroem os sujeitos -, compõe parte fundamental da categoria "ex-bandido". E a consciência do risco é produzida por meio de instrumentos simbólicos e discursivos oferecidos pela religião. Isto, de modo geral, é válido para todos aqueles que se convertem ao pentecos- 
talismo. Mas, no caso do "ex-bandido", é o reconhecimento de sua condição subjetiva que está em jogo. A marca social "bandido" é dotada de uma força extraordinária. Se é possível estar no crime, mas não ser "bandido" (como vimos nos casos de André e William), também há a possibilidade de, após a assimilação da marca social como verdade de si, "permanecer bandido" mesmo fora das atividades criminosas, mesmo depois de se converter. Como um entrevistado certa vez me contou: "Eu tenho marcas na alma que nunca mais vão me deixar e eu preciso lidar com elas todo dia, o tempo inteiro".

\section{CONSIDERAÇÕES FINAIS}

Procurei, com base em narrativas de vida de "ex-bandidos", trazer alguns elementos que nos permitam compreender o complexo processo de transição identitária que está em jogo na conversão religiosa do "bandido". Em um primeiro momento, pudemos observar como essa categoria não se refere apenas a um termo acusatório aplicado a quem pratica crimes. Trata-se de uma representação social ligada - ao menos no contexto deste trabalho - ao modo como o tráfico de drogas se organizou nas favelas cariocas. Assim, "bandido" pode ser pensado como uma categoria coletiva que tem a ver não somente com práticas rotuladas como ilegais ou criminosas, mas está, sobretudo, ligada a formas de sentir, agir e pensar. "Bandido" é uma representação social de uma condição subjetiva; uma marca social passível de manuseamento e assimilação como verdade de si. Em termos teóricos, o "bandido" é o sujeito criminal.

Desse modo, a conversão do "bandido" ao pentecostalismo não pode ser pensada apenas como adoção de novos valores e práticas, mas como uma estratégia de reconstrução do sujeito. Nesse sentido, a conversão religiosa tem como preocupação central não somente retirar o sujeito da "vida do crime", mas, sobretudo, tirar o crime de "dentro" do sujeito. A ideia é provocar no indivíduo uma "metamorfose subjetiva" - como aparece em uma das entrevistas: o "coração de pedra" deve se transformar em "coração de carne". Entretanto, a conversão religiosa produz um sujeito que precisa estar o tempo todo atento às "tentações demoníacas" que podem lhe "devolver a subjetividade criminosa". A categoria "ex-bandido", assim, tem como componente fundamental a consciência dos riscos relacionais contidos no processo de construção de si. É preciso que o "ex-bandido" esteja atento e vigilante em todas as suas relações para que não ceda às "tentações demoníacas" 
e permaneça sempre convertido (e não-bandido). A consciência de que a conversão é um processo constante de elaboração de si compõe parte importante de "ex-bandido" como marca social e, em certa medida, pode ser entendido como resultado do próprio processo de conversão do "bandido" ao pentecostalismo.

(Recebido para publicação em março de 2010)

(Versão definitiva em setembro de 2011)

\section{NOTAS}

1. Diferentemente do que pode parecer, essa convergência entre periferias urbanas, violência e crescimento pentecostal não é algo específico do Brasil. Freston (1994:112), ao fazer uma breve história do pentecostalismo brasileiro, já nos alertava que "a cidade norte-americana onde o pentecostalismo mais cresceu nos seus primeiros anos foi Chicago, onde $75 \%$ da população eram imigrantes ou filhos de imigrantes. Era a segunda cidade do país, com condições graves de exploração industrial e marcada pela violência cotidiana e pelo forte movimento operário. A modernidade dos arranha-céus com armação de aço convivia com condições sanitárias horrendas. Lá pululavam missões pentecostais das mais diversas etnias, inclusive entre os escandinavos".

2. Nesse sentido, podemos destacar o estudo de Dias (2008) sobre conversão ao pentecostalismo no contexto prisional. Em linhas gerais, a autora observa que a conversão religiosa de fato "protege" os evangélicos das violências cotidianas da prisão. Isso é tão evidente para os detentos que muitos deles realmente utilizariam a conversão apenas como forma de "proteção". O que geraria críticas por parte de pentecostais e não pentecostais. Segundo eles, tais pessoas estariam se "escondendo atrás da Bíblia". Mas Dias também observa os mecanismos para avaliar as intenções da conversão de um detento. E conclui dizendo que há um forte controle social por parte de prisioneiros, agentes penitenciários e diretores, de forma que a conversão só realmente funciona como mecanismo de proteção quando é vivenciada em toda sua radicalidade. Não basta apenas "aceitar Jesus de boca", mas vivenciar as práticas pentecostais em seus mínimos detalhes, para que a conversão tenha o efeito de "proteção".

3. O material empírico provém da pesquisa realizada para a produção da minha dissertação de mestrado (Teixeira, 2009). Para tanto, contei com o apoio financeiro do CNPq, que me concedeu uma bolsa de estudos de 2007 a 2009.

4. Aquilo a que nos referimos neste trabalho como "pentecostalismo" não é algo estático e homogêneo, mas dinâmico e plural. Freston (1994), por exemplo, divide o desenvolvimento do pentecostalismo brasileiro em três ondas: a primeira ocorre na década de 1910 e tem como contexto de surgimento o Norte do país e como principais representantes a Assembleia de Deus e a Congregação Cristã do Brasil; a segunda, no 
final da década de 1950 e no início da de 1960, tem como contexto de surgimento São Paulo e como principais representantes a Igreja Quadrangular, a Brasil para Cristo e a Deus é Amor; a terceira onda, que ocorre na década de 1970, tem o Rio de Janeiro como contexto de surgimento e como principais representantes a Igreja Universal do Reino de Deus e a Igreja Internacional da Graça de Deus - as denominações da terceira onda também são conhecidas como neopentecostais.

5. É importante lembrar que esta categoria nada tem de unívoca. Zaluar mesmo aponta diferenças internas entre os "chefes" e os "teleguiados", entre os "bandidos formados" e os "bichos soltos". No primeiro caso, há autonomia da ação e o poder de mando por parte dos chefes; e subordinação e obediência, por parte dos teleguiados. No segundo caso, a diferença, embora tenha também uma dimensão política - já que o bandido formado é mais respeitado pelos moradores e pelos outros "bandidos" que o bicho solto - reside no uso da violência. $\mathrm{O}$ "formado", entre outras coisas, é aquele que conhece as "regras do jogo": restringe o uso da violência apenas a situações especiais, seja para manter a ordem no morro seja dentro das guerras com quadrilhas rivais, para defender sua área. Já o bicho solto é um "bandido perverso", que usa indiscriminadamente a violência, seja contra moradores, contra membros da própria quadrilha e de quadrilhas rivais. De qualquer modo, como afirma a autora, a posse da arma de fogo e a "disposição para matar" alinham, de maneira geral, estas diferentes representações.

6. Grillo (2008), por exemplo, ao pesquisar o tráfico de drogas na classe média, mostra como os "traficantes do asfalto" apontam para a não-recorrência ao uso da violência como um elemento que os diferencia do "tráfico do morro".

7. Entretanto, como destaca Barbosa (1997), há a possibilidade do indivíduo se livrar dos castigos dependendo de sua "consideração" por parte dos próprios traficantes e dentro da comunidade.

8. No conjunto de entrevistas, há casos diversos de assimilação da sujeição criminal, que ocorrem em distintas situações de violência experimentadas pelos atores no contexto do comércio ilegal de drogas. Trago para o texto apenas o caso de William por ser uma narrativa que ajuda bastante a esclarecer as questões em jogo.

9. De acordo com Becker (2008), trata-se do indivíduo que é socialmente reconhecido como desviante, apesar de não adotar práticas rotuladas como desviantes. Nas palavras do autor, "a pessoa é vista pelos outros como se tivesse cometido uma ação imprópria, embora de fato não o tenha feito" (p. 32).

10. Diferentemente do que é apontado por Bourgois (1995), a adesão à identidade criminosa, no caso específico de William, não consiste em uma estratégia de valorização de uma posição social marginalizada, mas em uma estratégia de defesa frente ao próprio contexto do tráfico.

11. Inspirada em passagem bíblica do livro de Ezequiel (capítulo 36, versículo 26) que diz: "dar-vos-ei um novo coração e em vós porei um espírito novo; tirar-vos-ei do peito o coração de pedra e dar-vos-ei um coração de carne". 


\section{Cesar Pinheiro Teixeira}

\section{REFERÊNCIAS BIBLIOGRÁFICAS}

ALMEIDA, Ronaldo. (2006), “A Expansão Pentecostal: Circulação e Flexibilidade”, in F. Teixeira e R. Menezes (orgs.), As Religiões no Brasil: Continuidades e Rupturas. Petrópolis, Vozes, pp. 111-122.

e MONTERO, Paula. (1994), “Trânsito Religioso no Brasil". São Paulo em Perspectiva, vol. 15, no 3, pp. 92-101.

ALVITO, Marcos. (2001), As Cores de Acari: Uma Favela Carioca. Rio de Janeiro, FGV Editora.

BARBOSA, Antonio Rafael. (1997), Um Abraço para Todos os Amigos: Algumas considerações sobre o tráfico de drogas no Rio de Janeiro. Niterói, RJ, EdUFF.

BECKER, Howard S. (2008), Outsiders: Estudos de Sociologia do Desvio. Rio de Janeiro, Zahar.

BIRMAN, Patrícia. (1997), "Males e Malefícios no Discurso Pentecostal”, in P. Birman, R. Novaes e S. Crespo (orgs.), O Mal à Brasileira. Rio de Janeiro, EdUERJ.

BOURGOIS, Philippe. (1995), In Search of Respect. Selling Crack in El Barrio. Cambridge, Cambridge University Press.

CANO, Ignacio. (1997), A Letalidade da Ação Policial no Rio de Janeiro. Rio de Janeiro, Iser. . (1995), Uma Análise Espacial da Violência no Rio de Janeiro. Rio de Janeiro, Iser.

CIDADE DE DEUS. (2003), Direção: Fernando Meirelles e Katia Lund. Produção: O2 Filmes, Globo Filmes, Rio Filmes.

CONTINS, Marcia e GOLDMAN, Marcio. (1983), “O Caso da Pomba-Gira. Religião e Violência: Uma Análise do Jogo Discursivo entre Umbanda e Violência”. Religião \& Sociedade, vol. 11, no 1, pp. 103-132.

DAMATTA, Roberto. (1990), Carnavais, Malandros e Heróis: Para uma Sociologia do Dilema Brasileiro (5a ed.). Rio de Janeiro, Guanabara.

DIAS, Camila. (2008), A Igreja como Refúgio e a Bíblia como Esconderijo: Religião e Violência na Prisão. São Paulo, Humanitas.

FERNANDES, Rubem César (org.). (1998), Novo Nascimento: Os Evangélicos em Casa, na Igreja e na Política. Rio de Janeiro, Mauad.

FOUCAULT, Michel. (2006), A Hermenêutica do Sujeito. São Paulo, Martins Fontes.

FRESTON, Paul. (1994), “Uma Breve História do Pentecostalismo Brasileiro: A Assembleia de Deus". Religião e Sociedade, vol. 16, no 3, pp. 104-129.

GRILLO, Carolina. (2008), “O 'Morro' e a 'Pista': Um Estudo Comparado da Dinâmica do Comércio Ilegal de Drogas". Dilemas - Revista de Estudos de Conflito e Controle Social, vol. 1, pp. 127-148.

GOFFMAN, Erving. (1981), Forms of Talk. Philadelphia, University of Pennsylvania Press.

. (1976), "The Nature of Deference and Demeanor". Selected Papers from the American Anthropologist, 1946-1970. Washington, American Anthropological Association, pp. 208-237. 
. (1975), Estigma: Notas sobre a Manipulação da Identidade Deteriorada. Rio de Janeiro, Zahar.

. (1959), The Presentation of Self in Everyday Life. New York, Doubleday Anchor Books.

LEEDS, Elizabeth. (1998), "Cocaína e Poderes Paralelos na Periferia Urbana Brasileira”, in A. Zaluar e M. Alvito (orgs.), Um Século de Favela. Rio de Janeiro, FGV Editora.

LEITE, Márcia. (2009), “Religião e Política no Espaço Público: Movimentos de Moradores de Favelas contra a Violência e por Justiça", in R. Almeida e C. Mafra (orgs.), Religiões e Cidades. São Paulo, Terceiro Nome.

LINS, Paulo. (1997), Cidade de Deus. São Paulo, Companhia das Letras.

MAFRA, Clara. (1998), “Drogas e Símbolos: Redes de Solidariedade em Contextos de Violência", in A. Zaluar e M. Alvito (orgs.), Um Século de Favela. Rio de Janeiro, FGV Editora.

MAGGIE, Yvonne. (1992), Medo do Feitiço: Relações entre Magia e Poder no Brasil. Rio de Janeiro, Arquivo Nacional.

MARIZ, Cecília. (1999), “A Teologia da Batalha Espiritual: Uma Revisão da Bibliografia". RBIB-Revista Brasileira de Informação Bibliográfica em Ciências Sociais, no 47.

MASON, Laura. (2007), Feministas en todas Partes: Una Etnografia de Espacios y Narrativas Feministas en Argentina. Buenos Aires, Prometeu Libros.

MAUSS, Marcel. (2005), “A Expressão Obrigatória dos Sentimentos". Ensaios de Sociologia. São Paulo, Perspectiva.

. (2003), "Esboço de uma Teoria Geral da Magia", in Sociologia e Antropologia. São Paulo, Coseac e Naif.

MISSE, Michel. (1999), Malandros, Marginais e Vagabundos \& A Acumulação Social da Violência no Rio de Janeiro. Tese de Doutorado. IUPERJ, Rio de Janeiro.

POLLAK, Michael e SCHILTZ, Marie-Ange. (1991), "Les homosexuals Français face au Sida. Modifications des Pratiques Sexuelles et Émergence de Nouvelles Valeurs". Anthropologie et Sociétés, vol. 15, nos 2-3, pp. 53-62.

TEIXEIRA, Cesar Pinheiro. (2009), A Construção Social do "Ex-Bandido" - Um Estudo sobre Sujeição Criminal e Pentecostalismo. Dissertação de mestrado. Programa de Pós-Graduação em Sociologia e Antropologia da Universidade Federal do Rio de Janeiro.

. (2008), “O Pentecostalismo em Contextos de Violência: Uma Etnografia das Relações entre Evangélicos Pentecostais e Traficantes de Drogas em Magé". Ciências Sociais e Religião/Ciencias Sociales y Religión, no 10, pp. 181-205.

ZALUAR, Alba. (1997), “O Crime e a Não-cidadania: Os Males do Brasil”, in P. Birman, R. Novaes e S. Crespo (orgs.), O Mal à Brasileira. Rio de Janeiro, EdUERJ.

(1985), A Máquina e a Revolta: As Organizações Populares e o Significado da Pobreza. São Paulo, Brasiliense. 


\section{ABSTRACT}

From "Hearts of Stone" to "Hearts of Flesh": The Conversion of "Bandits" to Pentecostal Evangelical Churches

This article discusses several elements that allow understanding the conversion of "bandits" to Pentecostal Evangelical churches. The empirical material consisted basically of interviews with individuals who had "lived a life of crime" before converting to some Pentecostal denomination. The analysis is based on the idea of criminal subjection - meaning the social construction of the "bandit" as a subject. Criminal subjection is highlighted in the narratives of conversion. The study thus provides elements for understanding the construction of two identities that are strikingly present on the poor outskirts of Brazilian metropolitan areas and that constitute an important part of their daily reality: the "bandit" and the "believer".

Key words: criminal subjection; Pentecostalism; conversion; subjection 